\title{
Ediacaran organic-rich Kalus Beds of western Ukraine and NW Moldova: mineralogy, total organic carbon content and hydrocarbon potential
}

\author{
Natalia Radkovets, Myroslav Pavlyuk, Yaroslava Yaremchuk and Yuriy Koltun \\ Institute of Geology and Geochemistry of Combustible Minerals, National Academy of Sciences of Ukraine, Naukova $3 a, 79060$ \\ Lviv, Ukraine; radkov_n@ukr.net
}

Received 18 June 2021, accepted 17 October 2021, available online 15 November 2021

\begin{abstract}
The Ediacaran succession occurs at the southwestern slope of the East European Platform from the Black Sea to the LublinPodlasie Basin. It includes a black shale interval in Ukraine represented by the Kalus Beds which may have hydrocarbon source rock potential. Coeval organic-rich rocks are known to have sourced commercial accumulations of oil and gas in different parts of the world. In western Ukraine and NW Moldova, the thickness of the Kalus shales exceeds $90 \mathrm{~m}$. These strata crop out locally near the border of the Ukrainian Shield and dip in the southwestern direction towards the Teisseyre-Tornquist zone, reaching the depths of over $4000 \mathrm{~m}$. This paper presents a study of hydrocarbon source rock potential of the Kalus Beds and is based on the results of organic geochemical and mineralogical investigations. The organic-rich Kalus Beds are represented by clay-rich siltstone in which quartz (38-66\%) and mica (8-19\%) prevail over clay minerals. They also contain a significant amount of feldspar (4-11\%) and chlorite $(4-12 \%)$. The clay fraction is represented by illite, chlorite, kaolinite and illite-smectite. Mixed-layered clay minerals are distributed at burial depths of up to $150 \mathrm{~m}$. Kaolinite occurs in a wider range of depths, but below $3800 \mathrm{~m}$ clay minerals are represented exclusively by chlorite and illite. Such a proportion of mineral components of the analysed beds and the grain size of quartz indicate their high brittleness and thus suitability for efficient hydraulic fracturing. The total organic carbon content in the Kalus shales varies between 0.1 and $0.89 \mathrm{wt} \%$, exceeding $0.5 \mathrm{wt} \%$ in some parts of the study area, and thus these strata can be considered as a lowquality potential hydrocarbon source rock. The maturation level of the Kalus Beds clearly depends on the depth of burial. These rocks are immature till a depth of $100 \mathrm{~m}$. Generation windows for oil and gas occur within depth ranges from 100 to $2200 \mathrm{~m}$ and from 2200 to $3800 \mathrm{~m}$, respectively. At greater depths these rocks are overmature. In the main part of the study area, the organic-rich Kalus Beds have significant thickness and are matured to the level of oil and gas windows and hence might generate hydrocarbons and contribute to the development of the petroleum system in the region.
\end{abstract}

Key words: Kalus Beds, black shales, Ediacaran, Ukraine, mineral composition, total organic carbon, thermal maturity, hydrocarbons.

\section{INTRODUCTION}

The study area includes the Volyn-Podillyan Plate and the NW Moldovian Platform, which are part of the East European Platform (Fig. 1). Its sedimentary cover ranges in age from the Neoproterozoic to the Palaeozoic and comprises several organic-rich intervals, in particular in the Ediacaran, Cambrian, Silurian, Devonian and Carboniferous (Radzivil et al. 2012; Krupsky et al. 2014; Radkovets 2016; Kosakowski et al. 2017; Radkovets et al. 2017a, 2017b, 2018; Poprawa et al. 2018).

Detailed investigations of the sedimentary strata of western Ukraine and adjacent parts of Moldova began in the late 1970s and early 1980s when deep boreholes pene- trating the submerged edge of the platform were drilled to study the oil and gas potential of the area. Despite the significant extent of geological and geophysical studies of the region, to date only two commercial gas fields and one non-commercial oil accumulation have been discovered in the Middle Devonian deposits of the Volyn-Podillyan Plate (Krupsky et al. 2014). In addition, numerous oil and gas shows have been recorded in the Cambrian and Silurian strata (Khizhnyakov 1963; Dolenko et al. 1984; Trushkevich \& Shvay 1998; Krupsky et al. 2014). These data indicate the potential for further exploration for hydrocarbons within the study area.

The organic-rich Ediacaran strata of the late Neoproterozoic are among the oldest sediments, distributed 


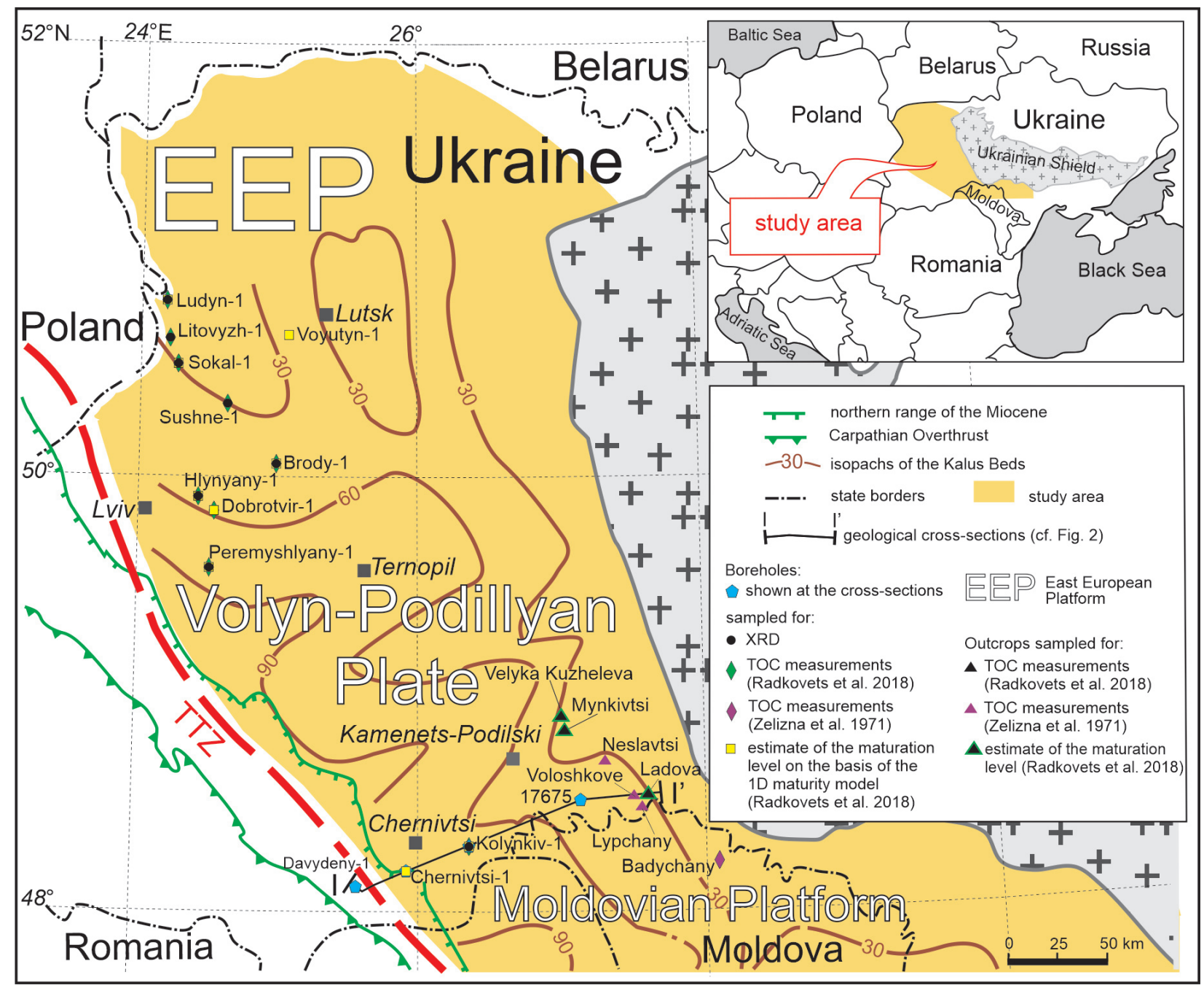

Fig. 1. Location map, showing the distribution and thickness of the organic-rich Ediacaran Kalus Beds within western Ukraine and NW Moldova and the studied boreholes. TTZ, Teysseyre-Tornquist Zone (modified after Radkovets et al. 2018).

along the entire SW slope of the East European Platform from the Black Sea to the Lublin-Podlasie Basin. Moreover, they globally occur in almost all cratons of the world (Vecoli 2013). These deposits are of considerable interest also because an outbreak of organic life in the oceans took place during the Ediacaran period, while postglaciation global anoxic events resulted in organic matter preservation (Craig et al. 2014). This is reflected in the sedimentary record by black shales of high thickness, which are source rocks for hydrocarbons in many sedimentary basins of the world (Radkovets et al. 2018).

In the context of petroleum geology, the Ediacaran deposits of the Volyn-Podillyan Plate and NW Moldovian Platform, in particular the organic-rich Kalus Beds with total organic carbon (TOC) contents mostly exceeding $0.5 \mathrm{wt} \%$, are the least investigated strata in the sedimentary sequence of the study area. The objective of this study is to show the mineral composition and distribution of TOC in the Kalus Beds, reveal spatial and depth-related changes in their thermal maturity, delineate the location of hydrocarbon generation windows within the study area and determine their hydrocarbon generation potential and thus the possible role of these deposits in petroleum systems of the region.

\section{GEOLOGICAL SETTING}

The study area is the SW part of the East European Platform in western Ukraine and NW Moldova (Fig. 1). It is bordering the Ukrainian Shield in the NE, while towards the SW, the Neoproterozoic and Palaeozoic sedimentary cover is buried beneath the Carpathian Foredeep. The Archaean-Proterozoic heterogeneous 
basement is composed of metamorphic, ultrametamorphic, intrusive and metasomatic rocks. The overlying sedimentary cover comprises Neoproterozoic (Cryogenian, Ediacaran), Palaeozoic (Cambrian, Ordovician, Silurian, Devonian, Carboniferous), Mesozoic (Jurassic, Cretaceous) and Cenozoic (Palaeogene, Neogene, Quaternary) deposits. The thickness of the sedimentary cover increases from NE to SW, from a few hundred metres close to the Ukrainian Shield to over $5 \mathrm{~km}$ near the Teisseyre-Tornquist zone (Fig. 1; Kruglov \& Tsypko 1988; Chebanenko et al. 1990).

Figure 2 shows the geological cross-section through the SE part of the Volyn-Podillyan Plate, with the Palaeozoic succession wedging out in its NE part but being most complete and of maximum thickness and depth in its SW part. Unlike the Palaeozoic sequence, the Ediacaran strata are preserved in a complete stratigraphic section. Their thickness ranges between 100 and $300 \mathrm{~m}$ within the entire Volyn-Podillyan Plate despite a significant increase in the burial depth towards the NW (Radkovets et al. 2018; Fig. 3). The structural map of the top of the Ediacaran strata, constructed on the basis of well-log data from 135 boreholes located over the entire study area, is shown in Fig. 4. The data from the archives of the Institute of Geology and Geochemistry of Combustible Minerals of NAS of Ukraine, as well as of sections published by Velikanov et al. (1983) and Chebanenko et al. (1990), were used.

The thickness of the Ediacaran Kalus shales ranges from 30 to over $90 \mathrm{~m}$ within the major part of the VolynPodillyan Plate and the NW Moldovian Platform (Fig. 1). The Ediacaran strata are cropping out at the surface near the Ukrainian Shield in the valley of the Dnister River and its left tributaries. In the so-called basic section of
Podillya (Velikanov et al. 1983; Velikanov 2011), the entire Ediacaran sequence, including the Kalus Beds, occurs in surface outcrops. Numerous soft-bodied faunal fossils have been found there and their vertical range has been established. The levels of abundant and stratigraphically important bioglyphs have been described. A considerable occurrence of Vendotenides has been revealed and systematized. Based on these investigations (Palij 1976; Gnilovskaya 1979; Ishchenko 1983; Velikanov et al. 1983; Velikanov 1985, 2011; Aseeva 1988; Gnilovskaya et al. 1988; Gureev 1988), both the palaeontological and lithological aspects of the basic section of Podillya have been characterized with separation of the regional stratigraphic scale. The stratigraphy of the Neoproterozoic strata of the East European Platform has also been studied (Sokolov 1997; Makhnach \& Veretennikov 2003). In this study, we used the stratigraphic subdivision (Velikanov et al. 1983; Velikanov 2011) of the shale interval of clay-rich siltstones and mudstones of the Kalus Beds together with the overlying Neoproterozoic (Ediacaran, Upper Vendian) Kanyliv Series and Mogyliv-Podilsk Series (Nagoryany Stage) (Fig. 5). However, according to Paszkowski et al. (2021), the Kanyliv Series is of Cambrian age.

\section{MATERIAL AND METHODS}

Figure 1 shows the outcrops and boreholes investigated within the study area of the Volyn-Podillyan Plate and NW part of the Moldovian Platform. In total, nine rock samples were collected from the Kalus Beds of the VolynPodillyan Plate for mineral composition analyses using $\mathrm{X}$-ray diffraction. The samples were taken from eight

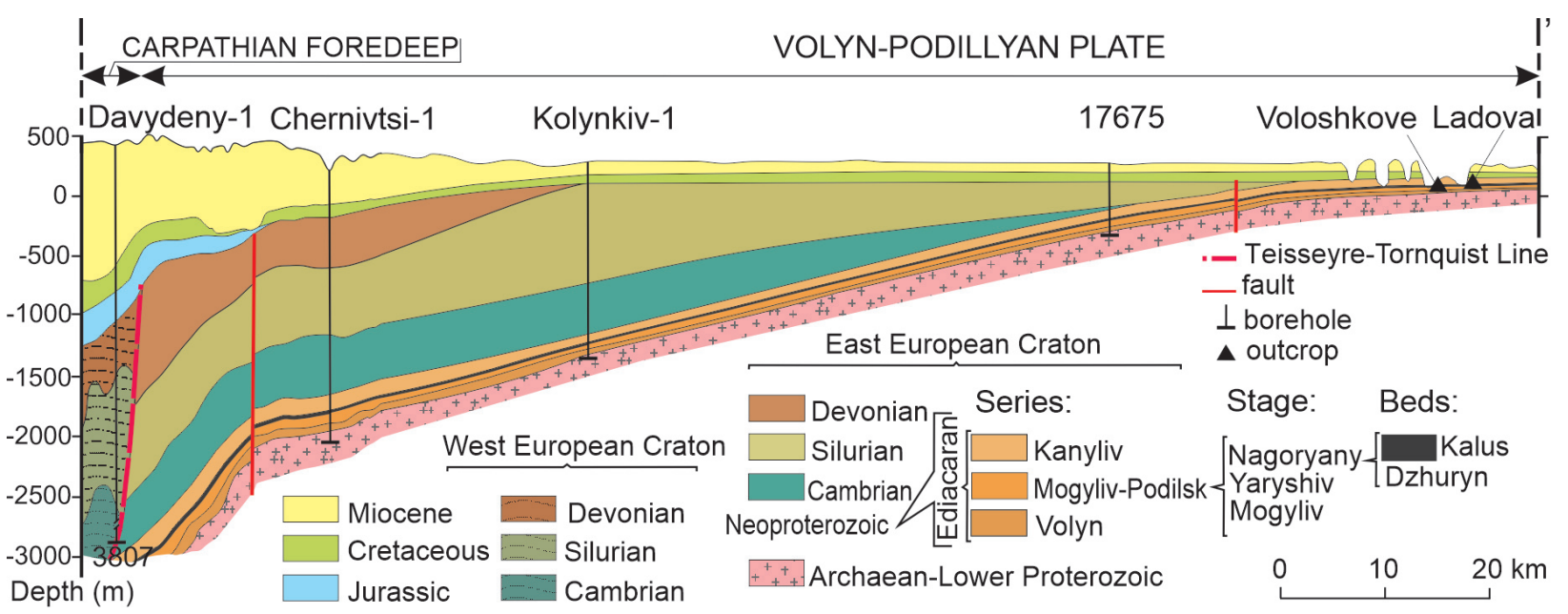

Fig. 2. Geological cross-section I-I' through the Carpathian Foredeep and the Volyn-Podillyan Plate (see Fig. 1 for location) (modified after Vashchenko et al. 2007; Bratslavskiy et al. 2008). 


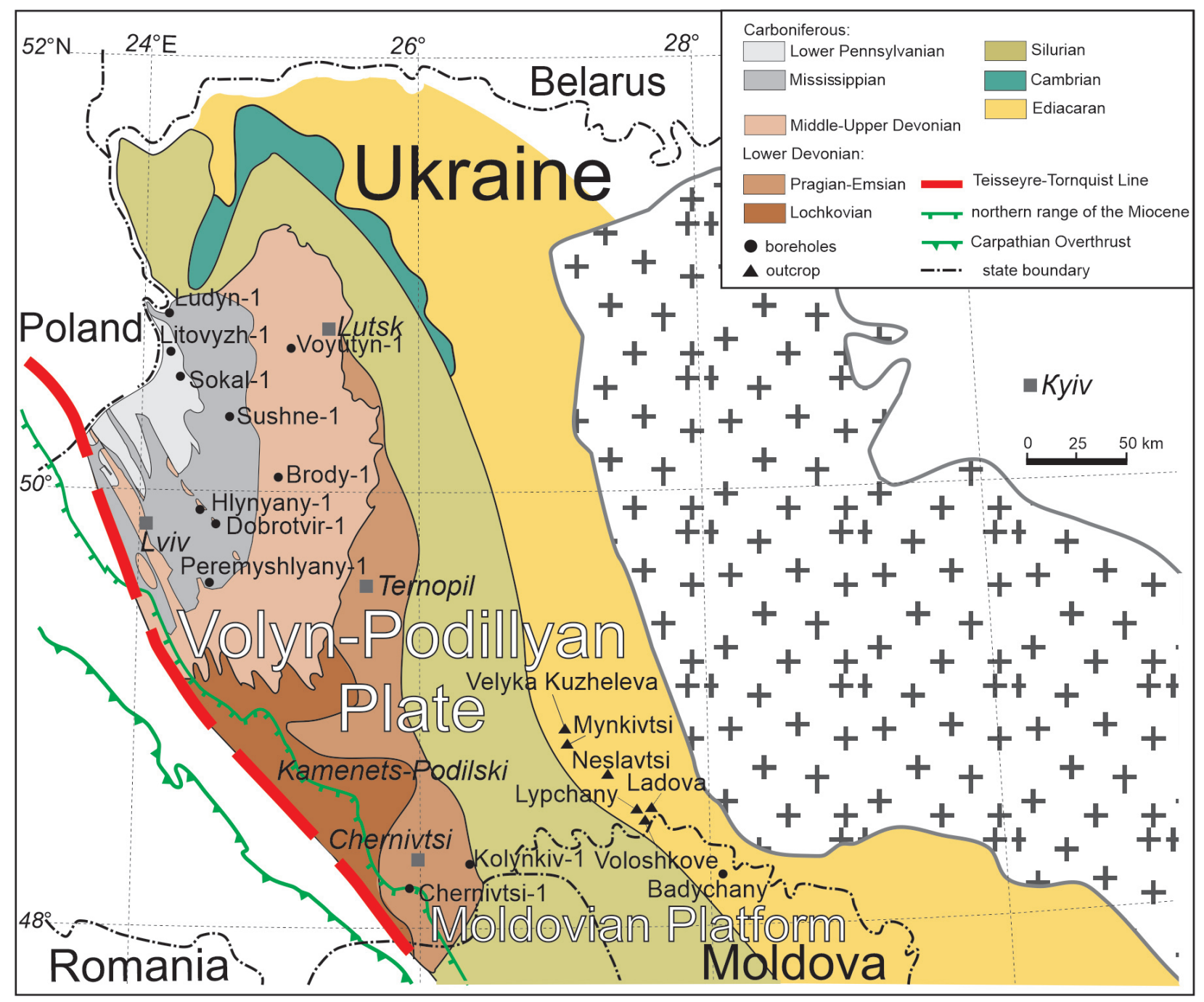

Fig. 3. Geological map of the southwestern margin of the East European Platform without the Mesozoic and Cenozoic (modified after Velikanov et al. 1983; Chebanenko et al. 1990; Gnidets et al. 2002; Shul'ga et al. 2007; Poprawa et al. 2018).

boreholes (Kolynkiv-1, Brody-1, Sushne-1, Hlynyany-1, Peremyshlyany-1, Ludyn-1, Litovyzh-1, Sokal-1) and one surface outcrop in the valley of the Dnister River near the village of Mynkivtsi.

We also used the results of previous studies of the TOC content and thermal maturity of the Kalus Beds. These included data from nine boreholes (Kolynkiv-1, Brody-1, Sushne-1, Dobrotvir-1, Hlynyany-1, Peremyshlyany-1, Ludyn-1, Litovyzh-1, Sokal-1) and three surface outcrops in the valley of the Dnister River and its left tributaries near the villages of Ladova, Mynkivtsi and Velyka Kuzheleva, of the Volyn-Podillyan Plate (Radkovets et al. 2018). Moreover, we incorporated the results of TOC measurements of the Kalus Beds from the Badychany-1 borehole in the Moldovian Platform and three surface outcrops in the valley of the Dnister River and its left tributaries near the villages of Lypchany, Neslavtsi and Voloshkove of the Volyn-Podillyan Plate from Zelizna et al. (1971).

The XRD study of the organic-rich Kalus Beds was performed in the laboratory of the Institute of Geology and Geochemistry of Combustible Minerals of NAS of Ukraine, Lviv, Ukraine, by means of standard methods (Zevin \& Zavyalova 1974; Frank-Kamenetskij 1983; Moore \& Reynolds 1997), using an ADP-2.0 diffractometer. The XRD system operated under the following conditions: $34 \mathrm{kV}, 14 \mathrm{~mA}$, Mn-filtered Fe radiation, at $0.025^{\circ} 2 \Theta /$ step using the counting time of $1.5 \mathrm{~s}$.

For grain-size analysis, the selected rock samples were ground to $3 \mathrm{~mm}$ particles and disintegrated by prolonged exposure to distilled water. The complete disintegration of the rock samples took about a year. The sand fraction 


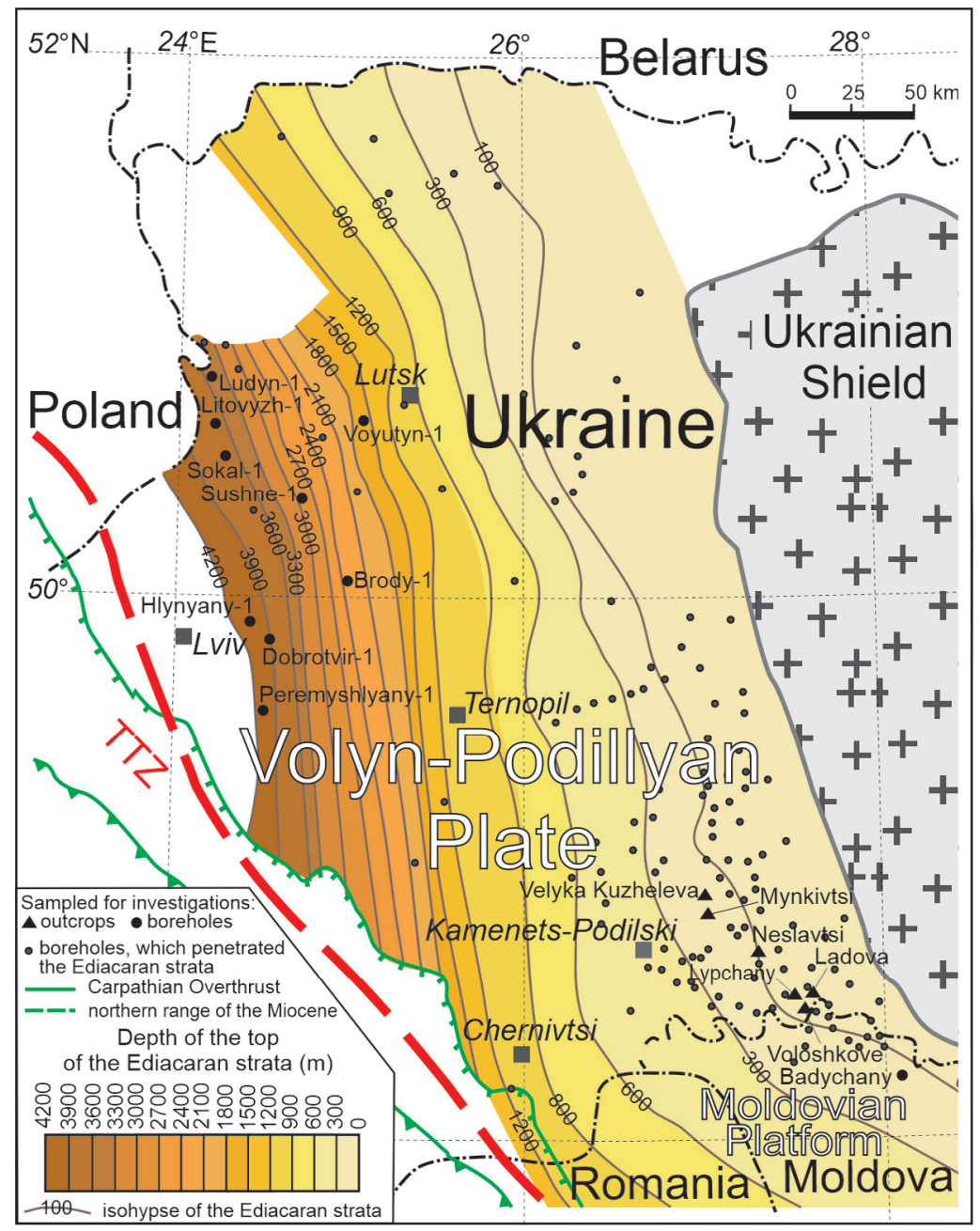

Fig. 4. Structural map of the top of the Ediacaran strata of the Volyn-Podillyan Plate and the NW Moldovian Platform. The map was constructed using the well-log data from the archives of the Institute of Geology and Geochemistry of Combustible Minerals of NAS of Ukraine as well as of sections, published by Velikanov et al. (1983) and Chebanenko et al. (1990). TTZ, Teysseyre-Tornquist Zone.

\begin{tabular}{|c|c|c|c|c|c|}
\hline \multirow{2}{*}{$\begin{array}{l}\text { Age } \\
\text { (MMa) } \\
542\end{array}$} & \multirow{2}{*}{ Era- } & \multirow{2}{*}{ System } & \multicolumn{3}{|c|}{ Regional } \\
\hline & & & Series & Stages & Beds \\
\hline & \multirow{7}{*}{ 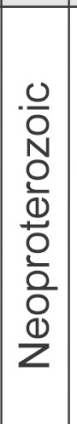 } & \multirow{7}{*}{ 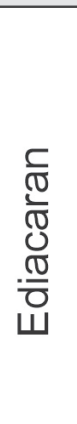 } & \multirow{3}{*}{ 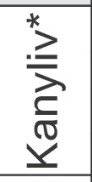 } & Studennytsya & \\
\hline & & & & Krushanivka & \\
\hline & & & & Zharnivka & \\
\hline & & & \multirow{4}{*}{ 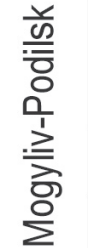 } & \multirow[b]{2}{*}{ Nagoryany } & Kalus \\
\hline & & & & & Dzhuryn \\
\hline & & & & Yaryshiv & \\
\hline & & & & Mogyliv & \\
\hline
\end{tabular}

Fig. 5. Stratigraphic scheme of the Ediacaran (Upper Vendian) succession of the Volyn-Podillyan Plate (modified after Velikanov 2011). *According to Paszkowski et al. (2021), the Kanyliv Series is of Lower Cambrian age. was removed from the disintegrated rock by gravity deposition (1-2 min). The siltstone and clay fractions were separated by centrifugation (Moore \& Reynolds 1997). The purpose of particle size separation was to detach the mass fraction of total clay from the rock.

In order to determine the clay mineral associations, the XRD patterns of oriented preparations (air-dried, saturated with ethylene glycol, heated at $550{ }^{\circ} \mathrm{C}$, washed with a solution of $15 \% \mathrm{HCl}$ ) of 1-dimensional X-ray spectra were analysed. The mineral composition of the rocks was studied using the diffractograms of the powder (without separation, mechanically ground) and the oriented (after separation of the gravity precipitated fraction less than $\leq 2 \mu \mathrm{m})$ samples. The disintegration of samples was performed for the determination of the mass fraction total clay $(\leq 4 \mu \mathrm{m})$ and investigation of clay minerals composition. To eliminate the negative impact of organic matter 
adsorbed by clay particles on the registration of basal reflexes, the pellet fraction was treated for a long time with $30 \% \mathrm{H}_{2} \mathrm{O}_{2}$ solution before XRD study. In order to diagnose kaolinite in the presence of chlorite, samples of the pellet fraction were additionally treated with hot $15 \%$ $\mathrm{HCl}$ solution for $3 \mathrm{~h}$.

The quantitative distribution of clay minerals in the pelitic fraction was determined by the simulation of 1-dimensional XRD patterns of disordered layered minerals using PyXRD-0.7.2 software (Clause 2016).

To identify non-clay minerals in the rock, the average mixture of sand and silt fractions (particles $>8 \mu \mathrm{m}$ ) was investigated. The XRD spectra of undirected powder samples of these mixtures were analysed. The quantitative mineral content in the sand-silt fraction was determined using the program Profex-8.4, based on the modelling of diffractogram profiles by the Rietveld method (Döbelin \& Kleeberg 2015). Its essence is to clarify, using the method of least squares, the profile structural parameters in the process of comparing the calculated and experimental diffractograms in order to minimize their difference. Based on the grain size distribution of fractions and the quantitative content of minerals in them, de- termined by XRD studies, normalized diagrams were constructed.

\section{RESULTS AND DISCUSSION}

\section{Mineral composition}

The results of XRD study indicate that the organic-rich dark-coloured rocks of the Kalus Beds have heterogeneous mineral composition (Table 1). Whole-rock samples include quartz, feldspar, chlorite, mica and clay minerals (Fig. 6A). Clay fraction samples comprise illite, kaolinite, chlorite and illite-smectite (Fig. 6B). It should be noted that chlorite in the rock occurs in two forms: layered aluminosilicate (Fig. 6A) and its fine-dispersed variety, treated as clay mineral (Fig. 6B).

Lithologically the Kalus Beds are represented by mudstones and clay-rich siltstones (Radkovets et al. 2018). Quartz grains correspond in their size to very fine sand $(0.125-0.062 \mathrm{~mm})$ and coarse silt $(0.031-0.062 \mathrm{~mm})$ fractions. Since all samples analysed by XRD contain less than $50 \%$ total clay, they were classified as clay-rich siltstones.

Table 1. Mineral composition of the Ediacaran Kalus Beds based on the results of XRD study

\begin{tabular}{|c|c|c|c|c|c|c|c|c|c|c|c|c|}
\hline \multirow[t]{2}{*}{ Outcrop/Borehole } & \multirow[t]{2}{*}{ Depth (m) } & \multirow[t]{2}{*}{ Lithology } & \multirow[t]{2}{*}{$\begin{array}{l}\text { TOC* } \\
\left(w t^{*} \%\right)\end{array}$} & \multicolumn{5}{|c|}{ Whole-rock mineral content $(\%)$} & \multicolumn{4}{|c|}{$\begin{array}{l}\text { Mineral content of clay } \\
\text { fraction }(\%)\end{array}$} \\
\hline & & & & $\mathrm{Q}$ & Fs & $\mathrm{Ch}$ & $\mathrm{Mi}$ & $\mathrm{TC}$ & It & $\mathrm{Ch}$ & $\mathrm{I} / \mathrm{S}$ & $\mathrm{K}$ \\
\hline Mynkivtsi & Outcrop & $\begin{array}{l}\text { Clay-rich } \\
\text { siltstones }\end{array}$ & 0.89 & 37.6 & 0 & 9.4 & 15.66 & 36.45 & 58 & 3 & 23 & 16 \\
\hline Kolynkiv-1 & $1107-1111$ & $\begin{array}{l}\text { Clay-rich } \\
\text { siltstones }\end{array}$ & 0.48 & 45.88 & 11.26 & 4.02 & 19.31 & 19.06 & 73 & 27 & 0 & 0 \\
\hline Brody-1 & 2009-2010 & $\begin{array}{l}\text { Clay-rich } \\
\text { siltstones }\end{array}$ & 0.24 & 49.95 & 10.65 & 10.65 & 10.64 & 17.87 & 76 & 23 & 0 & 0 \\
\hline Sushne-1 & $2948-2954$ & $\begin{array}{l}\text { Clay-rich } \\
\text { siltstones }\end{array}$ & 0.43 & 34.29 & 11.43 & 11.43 & 19.5 & 23.37 & 76 & 14 & 0 & 10 \\
\hline Ludyn-1 & 3227 & $\begin{array}{l}\text { Clay-rich } \\
\text { siltstones }\end{array}$ & 0.39 & 48.16 & 4.01 & 12.04 & 16.05 & 19.35 & 77 & 10 & 0 & 13 \\
\hline Sokal-1 & $3484-3506$ & $\begin{array}{l}\text { Clay-rich } \\
\text { siltstones }\end{array}$ & 0.84 & 66.41 & 4.48 & 8.08 & 10.77 & 9.42 & 84 & 16 & 0 & 0 \\
\hline Litovyzh-1 & $3535.8-3543.1$ & $\begin{array}{l}\text { Clay-rich } \\
\text { siltstones }\end{array}$ & 0.46 & 60.15 & 11.5 & 8.85 & 7.96 & 11.08 & 64 & 17 & 0 & 19 \\
\hline Hlynyany-1 & $3950.2-3954.7$ & $\begin{array}{l}\text { Clay-rich } \\
\text { siltstones }\end{array}$ & 0.20 & 50.73 & 7.37 & 9 & 14.72 & 17.98 & 75 & 25 & 0 & 0 \\
\hline Peremyshlyany-1 & $4039-4044$ & $\begin{array}{l}\text { Clay-rich } \\
\text { siltstones }\end{array}$ & 0.23 & 52.4 & 7.61 & 9.3 & 15.2 & 15.26 & 79 & 21 & 0 & 0 \\
\hline
\end{tabular}

TOC, total organic carbon; Q, quartz; Fs, feldspar; Ch, chlorite; Mi, mica; TC, total clay; It, illite; K, kaolinite; I/S, illite-smectite

* - data after Radkovets et al. (2018). 


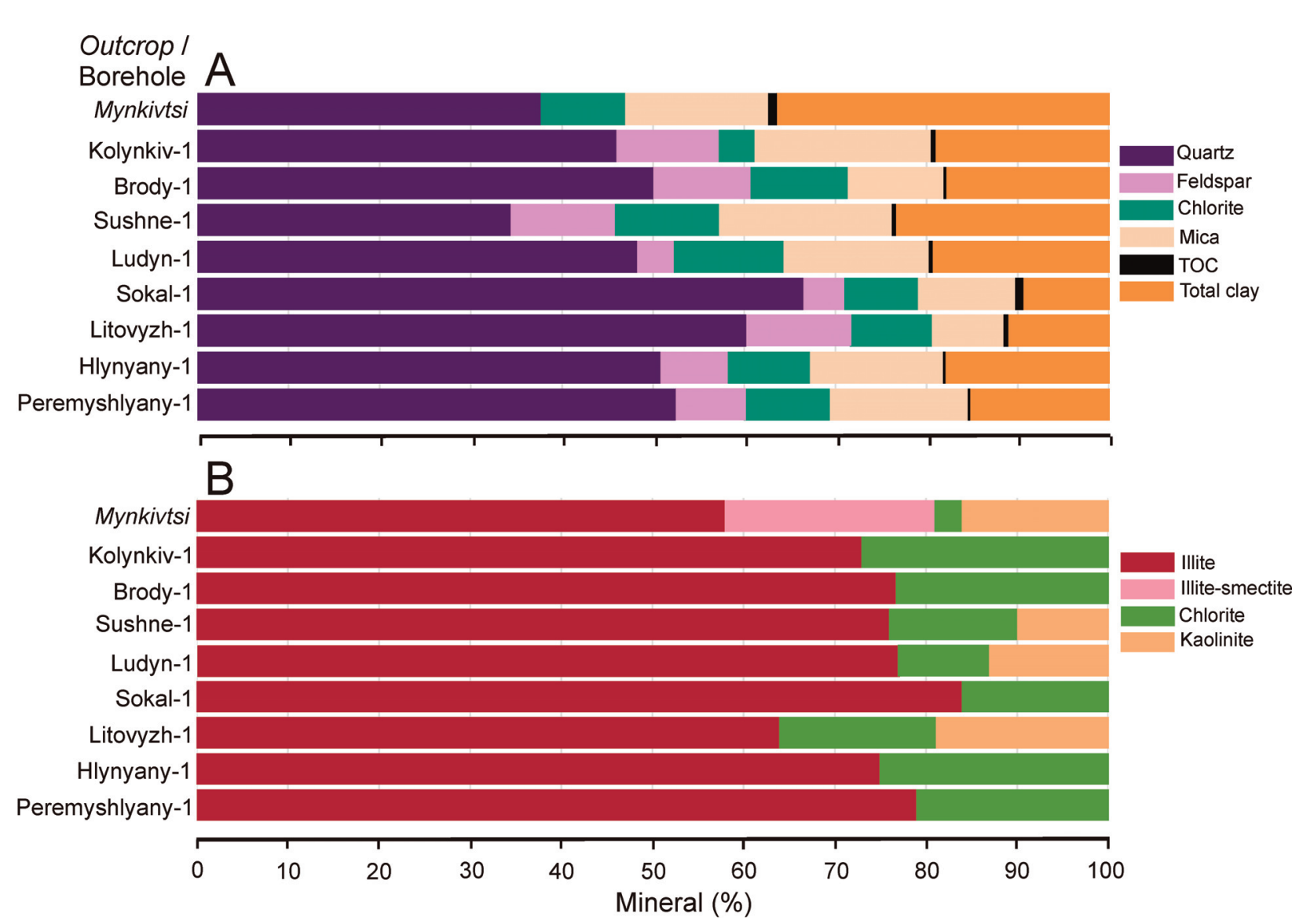

Fig. 6. Mineralogy of the Ediacaran Kalus rocks. A, whole-rock samples. B, clay fraction samples. TOC content data after Radkovets et al. (2018).

Figure 7 shows the results of XRD analysis, presented as circle diagrams of selected samples of the Kalus Beds from different parts of the study area covering a wide range of depths. They include a sample from the Mynkivtsi outcrop and core samples from the Sushne-1 $(3100 \mathrm{~m})$ and Peremyshlyany-1 (4200 m) boreholes. Based on the lines observed in the XRD patterns of the powder preparations (Fig. 7AI-III), the mineral composition of the Kalus Beds was determined, indicating the presence of an association of quartz, feldspar, chlorite, mica and total clay. Quartz grains were identified on peaks $0.424,0.334,0.245,0.228,0.212$ and $0.1812 \mathrm{~nm}$ and feldspar on $0.321 \mathrm{~nm}$. The layered aluminosilicates comprise mica $(1.0,0.49,0.45$ and $0.256 \mathrm{~nm})$ and chlorite $(1.38,0.71$ and $0.354 \mathrm{~nm})$.

Detailed investigations of the clay fraction in nontreated (air-dried) ( $a$ in Fig. 7BI-III), saturated with ethylene glycol ( $b$ in Fig. 7BI-III), heated at $550{ }^{\circ} \mathrm{C}(c$ in Fig. 7BI-III) and washed with a solution of $15 \% \mathrm{HCl}$ ( $d$ in Fig. 7BI-III) oriented samples showed that the clay fraction in all the samples was represented by chlorite and illite. These minerals were identified by the characteristic maxima that do not change their positions after saturation with ethylene glycol and remain after heating. Kaolinite was identified in some samples (Fig. 6) by a clear reflex of $0.71 \mathrm{~nm}$ ( $d$ in Fig. 7BI-II). Apart from the clay minerals mentioned above, a sample from the Mynkivtsi outcrop contained mixed-layered illite-smectite, a mixed-layered mineral with illite layers predominating. It is reflected by small maxima from the side of small angles at the slope of reflex 001, characteristic of illite. It changes its position while saturation with ethylene glycol and disappears after heating at $550{ }^{\circ} \mathrm{C}$.

The XRD data showed that terrigenous constituent in the Kalus Beds significantly predominated over clay, and its content ranges from $64 \%$ to $90 \%$. The most common terrigenous mineral is quartz (38-66\%), while the amount of mica (8-19\%), feldspar (4-11\%) and chlorite (4-12\%) is much smaller. Illite significantly predominates in the clay fraction of clay-rich siltstones (58-68\%). Chlorite is found in smaller quantities in boreholes (10-27\%). Kaolinite is observed in four samples, with its content varying between $10 \%$ and $19 \%$. Mixed-layered mineral illite-smectite $(23 \%)$ was found only in the sample from 

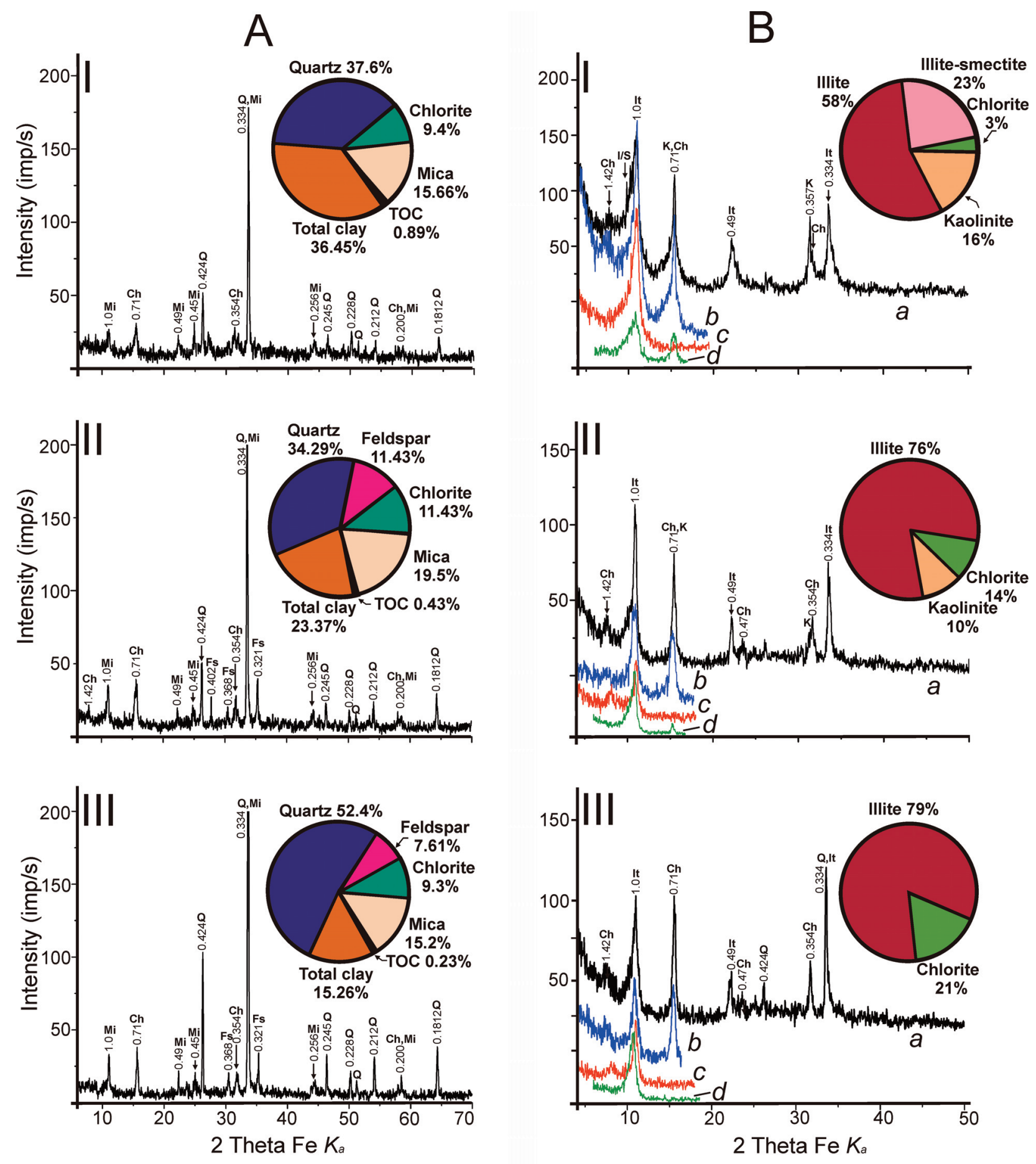

Fig. 7. Diffraction patterns and mineral composition of the Ediacaran Kalus Beds: I, from the Mynkivtsi outcrop; II, from the Sushne-1 borehole; III, from the Peremyshlyany-1 borehole. A, non-oriented whole-rock samples. B, oriented clay fraction samples (fraction finer than $2 \mu \mathrm{m}$ ): $a$, non-treated (air-dried); $b$, ethylene glycol solvated; $c$, heated at $550{ }^{\circ} \mathrm{C} ; d$, washed with a solution of $15 \% \mathrm{HCl}$. 
the outcrop, where Kalus rocks have not undergone significant post-sedimentary transformation.

Petrographic investigations of the Kalus rocks by Radkovets et al. (2018) showed also the presence of glauconite and phosphate, which were not determined in the present XRD study. Being a ferrous variety of hydromica, glauconite differs from illite in a lower peak $0.98 \mathrm{~nm}$ and since both illite and glauconite are present in the rock, it was impossible to distinguish between them. Small amounts of phosphate are at the edge of XRD sensitivity and were not detected either.

\section{TOC content}

As shown in Fig. 1, the Kalus Beds occur throughout the study area, and their thickness mostly ranges from 30 to $90 \mathrm{~m}$. Elevated organic matter content (Zelizna et al. 1971; Radkovets et al. 2018) allows, therefore, considering them as a target for organic geochemical studies. The TOC content, as a primary parameter for characterizing the hydrocarbon generation potential of the Kalus Beds, was studied both in boreholes and in outcrops. Investigations cover the southeastern and western parts of the study area (Fig. 8). In the southeastern part, the TOC content is highest $(0.89 \%)$ in the area adjacent to the Ukrainian Shield and it gradually decreases to $0.4 \%$ southwestwards in the dipping direction of the East European Platform. In the western part, the maximum TOC content $(0.84 \%)$ is observed in the area adjacent to the Polish border, decreasing southeastwards to $0.1 \%$. The TOC content in the Kalus shales remained unexplored in the central and northern parts of the study area (Fig. 8), but given the above data, we can also assume the presence of rocks enriched in organic matter there.

The data discussed above indicate that the organic matter content of the Kalus Beds is generally low to moderate and variable over the territory of the VolynPodillyan Plate and the NW Moldovian Platform. In the southeastern part of the study area, the TOC content shows a clear tendency to decrease with increasing depth,

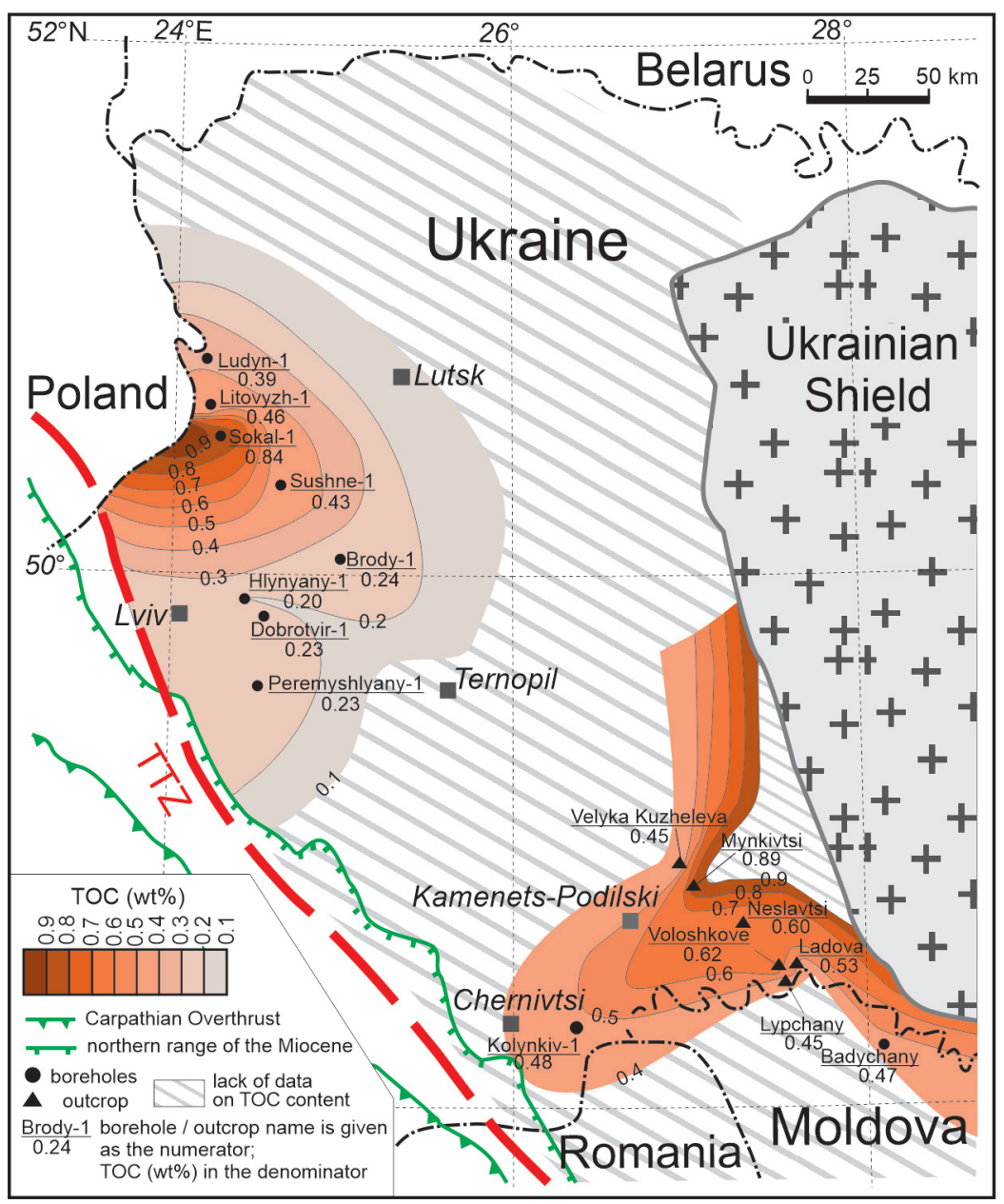

Fig. 8. Distribution of the TOC content in the Kalus Beds of the Volyn-Podillyan Plate and NW Moldovian Platform. 
while in the western part it is still elevated, although the Kalus shales occur here in a deeply buried part of the platform. These lateral TOC content changes are interpreted in terms of the existence of local shallow zones in the sedimentary basin during the Kalus Beds deposition time, which facilitated the accumulation of Vendotaenia antiqua - the main producers of organic matter in the Ediacaran sediments (Gnilovskaya 1979). Figure 9 shows the photomicrograph of the organic- and clay-rich siltstone from the Kalus Beds. According to Peters et al. (2007), sediments might be considered as potential source rocks if the TOC content in them is equal to or exceeding $0.5 \mathrm{wt} \%$. Our data showed that most of the analysed organic-rich shales of the Kalus Beds generally fall into the category of low-quality source rocks, but nevertheless these strata might have taken part in the formation of the petroleum systems within the study area.

\section{Thermal maturity and hydrocarbon generation windows}

The maturation level of the Ediacaran sediments depends on the depth of their occurrence. They are monoclinally dipping from the Ukrainian Shield southwestwards to the Teisseyre-Tornquist Zone (Fig. 4) due to the increase in the thickness of the Phanerozoic succession. Near the southwestern border of the Ukrainian Shield, the Ediacaran deposits occur at shallow depths, locally cropping out at the surface in the riverbed of the Dnister and its left tributaries. Figure 3 shows that the Ediacaran deposits

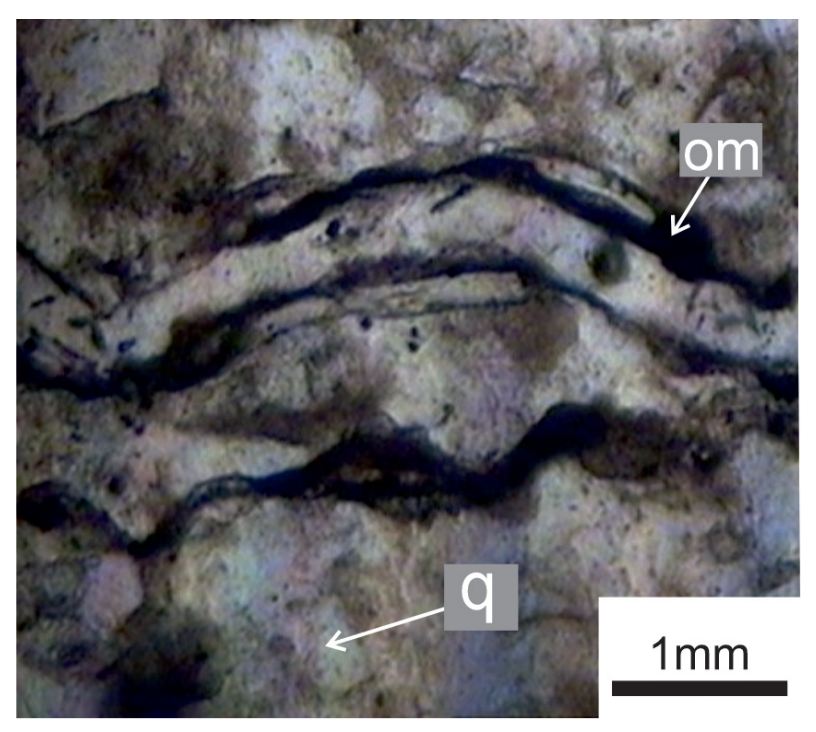

Fig. 9. Photomicrograph of the Ediacaran Kalus Beds sample from the Volyn-Podillyan Plate. Organic-rich clay-rich siltstone from the Sokal-1 borehole, depth interval 3484-3506 m; om, organic matter; q, quartz. are cropping out at the pre-Mesozoic surface within an approximately $50 \mathrm{~km}$ wide zone surrounding the Ukrainian Shield in the southwest, while towards the southwest they are buried beneath the Palaeozoic sediments. The geological cross-section through the southeastern part of the Volyn-Podillya Plate (Fig. 2) shows that the thick Silurian and Devonian strata which have been covering the Ediacaran sediments in the part adjacent to the Ukrainian Shield were cut by pre-Mesozoic erosion (Poprawa et al. 2018). As a result, Ediacaran strata in this part of the territory are overlain only by a thin (up to $50 \mathrm{~m}$ ) Cretaceous and Neogene sequence.

The Palaeozoic section covering the Ediacaran deposits increases in the southwestern direction. It is built up of the Middle-Upper Devonian and Carboniferous sequence in the northwestern part of the Volyn-Podillyan Plate (Figs 2, 3), affecting the depth of burial of the Ediacaran strata. The shallow dipping of Ediacaran strata close to the Ukrainian Shield is replaced southwestwards by their steeper sloping due to change in the lateral thickness of the overlying Cambrian and Silurian deposits. Rapid increase in the burial depth of the Ediacaran strata, related to increasing thickness of the Upper Palaeozoic, Mesozoic and Miocene successions, is observed in the zone adjacent to the Teisseyre-Tornquist Zone. Due to such a geological structure, the burial depth of the Ediacaran Kalus Beds varies from 0 to over $4000 \mathrm{~m}$ and provides a wide range of their maturation levels. Figure 10 shows that the rocks are immature in the vicinity of the Ukrainian Shield and their thermal maturity increases in the direction of immersion of the platform, reaching successively the oil generation zone, the gas generation zone and becoming overmature in the vicinity of the Teisseyre-Tornquist Zone. The lateral extent of these zones within the study area was identified based on the results of modelling the burial and maturation history of the Kalus Beds (Radkovets et al. 2018).

As the maturity of rocks depends on the depth of their occurrence, we can assume that the boundaries of hydrocarbon generation windows in the Ediacaran strata coincide with certain isohypses. According to the data by Radkovets et al. (2018), $T_{\max }$ values of the Kalus Beds from the Mynkivtsi, Velyka Kuzheleva and Ladova outcrops are 393,434 and $429^{\circ} \mathrm{C}$, respectively, showing that the rocks are immature close to the beginning of the oil window. Since the outcrops are located in deep canyons cut by tributaries of the Dnister River, as shown in Fig. 2, we assumed that the upper boundary of the oil window corresponded to the isohypse of $100 \mathrm{~m}$ (Fig. 4). The position of the lower boundary of the oil window was estimated by us on the basis of 1D maturity modelling (Radkovets et al. 2018) for the Voyutyn-1, Kolynkiv-1 and Chernivtsi-1 boreholes, in which the Kalus Beds occur within the oil window, and their relationship with the 


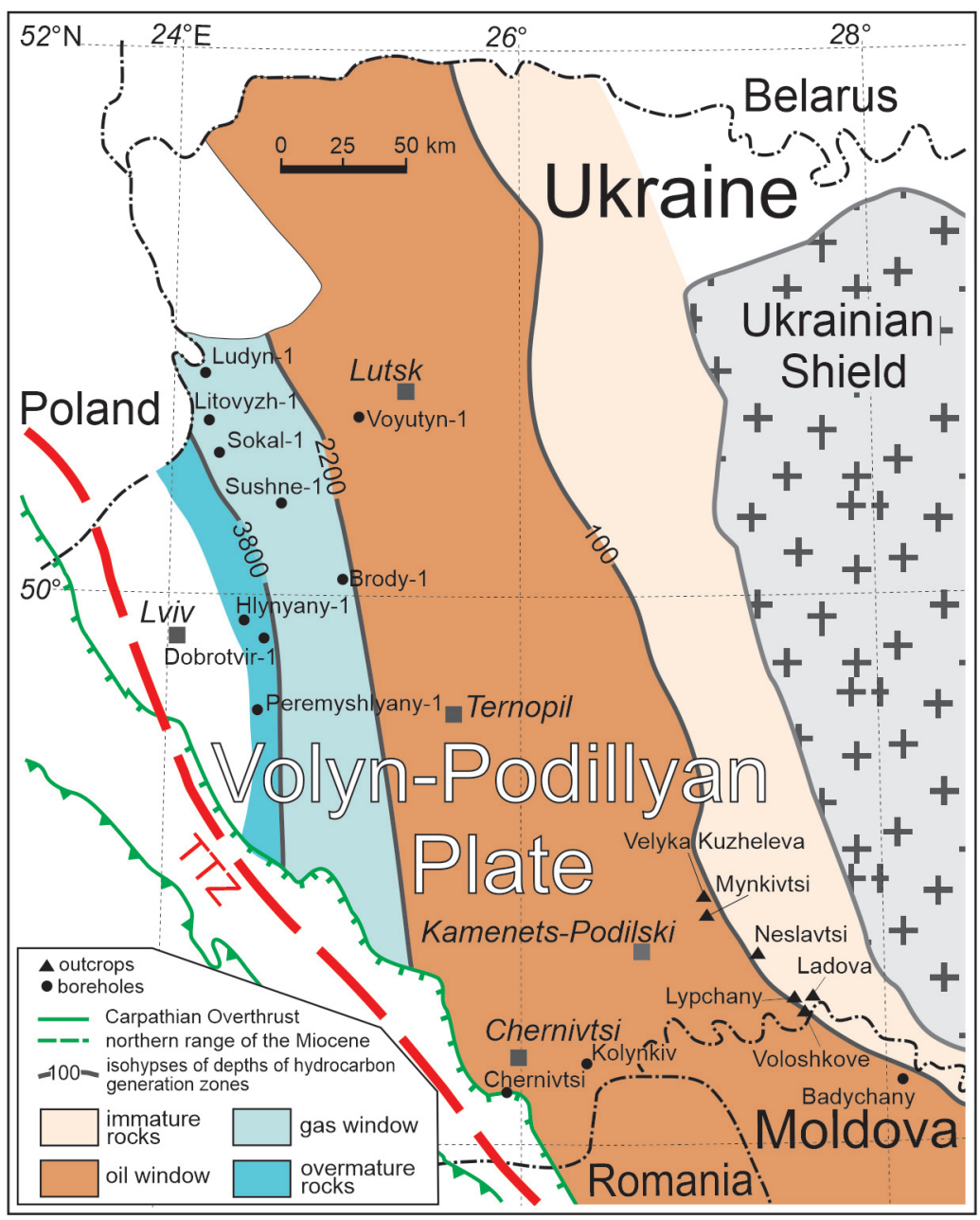

Fig. 10. Extent of hydrocarbon generation windows in the Ediacaran strata within the Volyn-Podillyan Plate and the NW Moldovian Platform. TTZ, Teysseyre-Tornquist Zone.

Brody-1 borehole, located at the top of the gas window. Thus, the boundary between oil and gas windows was shown at the $2200 \mathrm{~m}$ isohypse. According to the modelling results, the Kalus Beds in the Ludyn-1, Litovyzh-1, Sokal-1 and Brody-1 boreholes occur within the gas window. These strata are overmature in the Dobrotvir-1 borehole, being close to the lower limit of the gas window. Therefore, the lower boundary of the gas window is shown at the isohypse of $3800 \mathrm{~m}$. The rocks in the Peremyshlyany-1 borehole occur in the deeper part of the overmature zone.

Hence, the zone of immature rocks within a strip along the edge of the Ukrainian Shield has a burial depth varying from 0 to about $100 \mathrm{~m}$ (Fig. 10). The oil generation zone covers a large part of the study area where the Kalus Beds lie within the depth interval of 100$2200 \mathrm{~m}$. The gas generation zone is located on a steeper slope of the platform and extends in a narrow strip where the depth of the Kalus Beds ranges between 2200 and $3800 \mathrm{~m}$, passing to the SW into the zone of overmature rocks at greater depths. The increase in the maturation level towards the platform slope is also manifested in the change in the TOC content in the Kalus Beds. In the southeastern part of the study area, the TOC content decreases from 0.89 to $0.48 \mathrm{wt} \%$ with increasing depth and thermal maturity (Fig. 8), which probably reflects the intensification of the hydrocarbon generation processes. At the same time, in the western part of the study area, where Kalus rocks occur in a deeply buried part of the platform (depths over $3500 \mathrm{~m}$ ) and have a high maturation level (Radkovets et al. 2018), the TOC content reaches $0.84 \mathrm{wt} \%$, indicating that originally sediments were significantly enriched with organic matter.

The increase in the maturation level of the Kalus Beds towards the SW is also reflected in the composition of clay minerals. Figures 6, 7 and Table 1 show that closer to the 
Ukrainian Shield, where Kalus Beds occur at depths less than $150 \mathrm{~m}$ and crop out at the surface in the valley of the Dnister River and its left tributaries near the village of Mynkivtsi, clay minerals are represented by illite-smectite (23\%), illite (58\%), kaolinite (16\%) and a small amount of chlorite $(3 \%)$. As the depth of Kalus shales occurrence increases, illite-smectite disappears, kaolinite (10-19\%) is found only in some boreholes (Sushne-1, Ludyn-1, Litovyzh-1), chlorite ranges within $10-27 \%$ and the amount of illite increases (64-84\%).

The results of XRD analysis (Figs 6, 7; Table 1) show that in terms of petrographic composition, Kalus rocks within oil and gas windows (Brody-1, Kolynkiv-1, Litovyzh-1, Ludyn-1, Sokal-1 and Sushne-1 boreholes) are represented by clay-rich siltstones, the terrigenous component of which exceeds $75 \%$. No smectite or mixedlayered minerals with the swelling components have been found in these rocks. According to Burtner \& Warner (1986), Decker et al. (1992), Curtis (2002) and Jarvie et al. (2003), such a petrographic and mineralogical composition enhances the brittleness of rock, which shows that this formation might be suitable for hydraulic fracturing.

\section{CONCLUSIONS}

The Ediacaran Kalus Beds are an important organic-rich level within the sedimentary succession of the southwestern part of the East European Platform and thus the assessment of the role of these deposits in the petroleum system of the region is of considerable interest. The TOC content of Kalus Beds shales ranges between 0.2 and $0.89 \mathrm{wt} \%$ in the study region, generally exceeding $0.5 \mathrm{wt} \%$ in the NW area and in a great part of the SE area, and hence within a significant territory of western Ukraine and NW Moldova. Thus they might be regarded as potential hydrocarbon source rock.

The maturation level of Kalus rocks shows clear dependence on the burial depth, which increases southwestwards, i.e. in the direction of the Volyn-Podillyan Plate and the NW Moldovian Platform dip. In the eastern part of the study area, these strata crop out at the surface in the zone adjacent to the Ukrainian Shield, while in the SW, in close proximity of the Teisseyre-Tornquist Zone, their burial depth reaches more than $4000 \mathrm{~m}$. Accordingly, hydrocarbon generation zones were determined within the study area. Immature rocks occur in the depth range from 0 to $100 \mathrm{~m}$. The oil generation window covers a significant area within the depth interval from 100 to $2200 \mathrm{~m}$, passing to the SW to a gas generation window, which reaches a depth of $3800 \mathrm{~m}$. Farther southwestwards, the Kalus Beds are rapidly dipping and the rocks are overmature.
Lateral changes in the clay minerals content of the Kalus Beds also reflect the depth-dependence, as in the case of lateral changes in organic matter. The XRD analysis shows that illite-smectite occurs in the rocks only within the depths of up to $150 \mathrm{~m}$, that is in immature and early mature rocks. Within the zones of oil and gas generation, the rocks comprise kaolinite, chlorite and illite, while the overmature rocks contain only chlorite and illite. Lack of smectite or mixed-layered minerals with swelling components, as well as the increased terrigenous content in the Kalus rocks within oil and gas generation zones, causes their high brittleness, which makes this rock suitable for hydraulic fracturing.

Thus, the Kalus Beds, having a low to moderate TOC content and thermal maturity equivalent to oil and gas generation windows over the large territories of the VolynPodillyan Plate and the NW Moldovian Platform, can be considered as a potential source rock for hydrocarbons. It could thus contribute to the active petroleum system of the Neoproterozoic-Palaeozoic succession of the study area.

Acknowledgements. The authors are grateful to Dr Pawel Poprawa (Kraków, Poland) and the anonymous reviewer for helpful comments on an earlier version of the manuscript. The publication costs of this article were covered by the Estonian Academy of Sciences.

\section{REFERENCES}

Aseeva, E. A. 1988. Iskopaemye ostatki vendskikh talofitov [Fossil remains of Vendian talophytes]. In Biostratigrafiya $i$ paleogeograficheskie rekonstruktsii dokembriya Ukrainy [Biostratigraphy and Palaeogeographic Reconstructions of the Precambrian of Ukraine], pp. 81-102. Naukova Dumka, Kiev [in Russian].

Bratslavskiy, P. F., Shevchenko, O. M., Kuzmenko, L. S. \& Veklych, U. M. 2008. Derzhavna geologichna karta Ukrainy mashtabu 1: 200 000. Podilska seria. Arkush M-35- XXVIII (Mogyliv-Podilsk) [State Geological Map of Ukraine at a Scale of 1:200 000. Podillya Series. Sheet M-35- XXVIII (Mogyliv-Podilsk)]. UkrDGRI, Kiev [in Ukrainian].

Burtner, R. L. \& Warner, M. A. 1986. Relationship between illite/smectite diagenesis and hydrocarbon generation in Lower Cretaceous Mowry and Skull Creek Shales of the Northern Rocky Mountain area. Clays and Clay Minerals, 34, 390-402.

Chebanenko, I. I., Vishnyakov, I. B. \& Vlasov, B. I. 1990. Geotektonika Volyno-Podolii [Geotectonics of VolynoPodolia]. Naukova Dumka, Kiev, 244 pp. [in Russian].

Clause 2016. PyXRD: A Model for the Simulation of 1-Dimensional X-Ray Diffraction Patterns of Disordered Layered Minerals. Software Manual. Boston, USA, 48 pp.

Craig, J., Thurow, J., Thusu, B., Whitham, A. \& Abutarruma, Y. (eds). 2014. Global Neoproterozoic petroleum systems: The emerging potential in North Africa. Geological Society London Special Publications, 326, 1-25. 
Curtis, J. B. 2002. Fractured shale-gas systems. AAPG Bulletin, 86, 1921-1938.

Decker, A. D., Coates, J. M. \& Wicks, D. E. 1992. Stratigraphy, gas occurrence, formation evaluation and fracture characterization of the Antrimshale, Michigan Basin. GRI Topical Report, No. GRI-92/0258, 153 pp.

Döbelin, N. \& Kleeberg, R. 2015. Profex: a graphical user interface for the Rietveld refinement program BGMN. Journal of Applied Crystallography, 48, 1573-1580.

Dolenko, G. N., Rizun, B. P., Senkovskij, Y. N., Chizh, Y. I., Medvedev, A. P. \& Bojchuk, M. V. 1984. Geologiya $i$ neftegazonosnost' Volyno-Podol'skoj plity [Geology and Oil-and Gas-Bearing Potential of the Volyn-Podolsk Plate]. Naukova Dumka, Kiev, 106 pp. [in Russian].

Frank-Kamenetskij, V. A. 1983. Rentgenografiya osnovnykh tipov porodoobrazuyushchikh mineralov (sloistye i karkasnye silikaty) [Radiography of the Main Types of Rock-Forming Minerals (Layered Silicates and Skeleton Silicates]. Nedra, Leningrad, 359 pp. [in Russian].

Gnidets, V. P., Grigorchuk, K. G., Polukhtovych, B. M. \& Fedyshyn, V. O. 2002. Litohenez devonskykh vidkladiv Prydobrudzkoho prohynu (paleookeanohrafiya, sedymentatsiyna tsyklichnist, formuvannya porid-kolektoriv) [Lithogenesis of Devonian Deposits of Dobrogea Foredeep (Palaeooceanography, Sedimentary Cyclicity, Reservoir Rocks' Formation)]. UkrDGRI, Lviv, 85 pp. [in Ukrainian, with English abstract].

Gnilovskaya, M. B. 1979. Vendotenidy [Vendotenides]. In Paleontologiya verkhnedokembrijskikh i kembrijskikh otlozhenij Vostochno-Evropejskoj platformy [Palaeontology of the Upper Precambrian and Cambrian Deposits of the East European Platform], pp. 39-48. Nauka, Moscow [in Russian].

Gnilovskaya, M. B., Ishchenko, A. A., Kolesnikov, Ch. M., Korenchuk, L. V. \& Udal'tsov, A. P. 1988. Vendotenidy Vostochno-Evropejskoj platformy [Vendotenides of the East European Platform]. Nauka, Leningrad, 143 pp. [in Russian].

Gureev, Y. A. 1988. Besskeletnaya fauna venda [Skeletonless fauna of the Vendian]. In Biostratigrafiya $i$ paleogeograficheskie rekonstruktsii dokembriya Ukrainy [Biostratigraphy and Palaeogeographic Reconstructions of the Precambrian of Ukraine], pp. 65-80. Naukova Dumka, Kyiv [in Russian].

Ishchenko, A. A. 1983. K kharakteristike vendskoj vodoraslevoj flory Pridnestrovya [On the characteristics of the Vendian algal flora of the Dnister area]. In Stratigrafiya $i$ formatsii dokembriya Ukrainy [Stratigraphy and Precambrian Formations of Ukraine], pp. 181-206. Naukova Dumka, Kyiv [in Russian].

Jarvie, D. M., Hill, R. J., Pollastro, R. M., Wavrek, D. A., Claxton, B. L. \& Tobey, M. H. 2003. Evaluation of unconventional natural gas prospects in the Barnett Shale: fractured shale gas model. In European Association of International Organic Geochemists Meeting, Kraków, Poland, September 8-12, Book of Abstracts, Part II, pp. 34. Society of Research on Environmental Changes "Geosphere".

Khizhnyakov, A. V. 1963. Geologicheskoe stroenie i perspektivy neftegazonosnosti Lvovskogo paleozojskogo progiba
[Geological structure and oil and gas prospects of the Lvov Paleozoic trough]. In Geologiya i neftegazonosnost' territorii USSR [Geology and Oil- and Gas-Bearing Potential of the Territory of the Ukrainian SSR], pp. 189-202. Gostoptekhizdat, Moscow [in Russian].

Kosakowski, P., Radkovets, N., Rauball, J. \& Zakrzewski, A. 2017. Occurrence and burial and thermal history of the Ediacaran strata (W-SW Ukraine and Moldova). In 79th EAGE Conference \& Exhibition, Paris, France, pp. 101105. European Association of Geoscientists \& Engineers.

Kruglov, C. C. \& Tsypko, A. K. 1988. Tektonika Ukrainy [Tectonics of Ukraine]. Nedra, Moscow, 254 pp. [in Russian].

Krupsky, Y. Z., Kurovets, I. M., Senkovsky, Y. M., Mikhailov, V. A., Chepil, P. M., Drygant, D. M., Shlapinsky, V. E., Koltun, Y. V., Chepil, V. P., Kurovets, S. S. \& Bodlak, V. P. 2014. Netradytsiyni dzherela vuhlevodniv Ukrayiny [Nontraditional sources of hydrocarbons of Ukraine]. In Knyha 2, Zakhidnyy naftohazonosnyy rehion [Book 2, Western Oil and Gas Region]. Nika-Tsentr, Kyiv, 400 pp. [in Ukrainian].

Makhnach, A. S. \& Veretennikov, N. V. 2003. Korrelyatsiya stratigraficheskikh skhem venda Belarusi i drugikh rajonov Vostochno-Evropejskoj platformy [Correlation of the Vendian stratigraphic schemes of Belarus and other regions of the East European Platform]. In Stratigrafiya $i$ paleontologiya geologicheskikh formatsij Belarusi [Stratigraphy and Palaeontology of Geological Formations of Belarus], pp. 174-182. Institut geologicheskikh nauk NAN Belarusi, Minsk [in Russian].

Moore, D. M. \& Reynolds, R. C., Jr. 1997. X-Ray Diffraction and the Identification and Analysis of Clay Minerals. Oxford University Press, Oxford, New York, 378 pp.

Palij, V. M. 1976. Ostatki besskeletnoj fauny i sledy zhiznedeyatel'nosti iz otlozhenij verkhnego dokembriya i nizhnego kembriya Podolii [Remains of skeletonless fauna and traces of life activity from the sediments of the Upper Precambrian and Lower Cambrian of Podolia]. In Paleontologiya $i$ stratigrafiya verkhnego dokembriya $i$ nizhnego paleozoya yugo-zapada Vostochno-Evropejskoj platformy [Paleontology and Stratigraphy of the Upper Precambrian and Lower Palaeozoic of the Southwest of the East European Platform], pp. 63-77. Naukova Dumka, Kyiv [in Russian].

Paszkowski, M., Budzyń, B., Mazur, S., Sláma, J., Środoń, J., Millar, I. L., Shumlyanskyy, L., Kędzior, A. \& Liivamägi, S. 2021. Detrital zircon U-Pb and $\mathrm{Hf}$ constraints on provenance and timing of deposition of the Mesoproterozoic to Cambrian sedimentary cover of the East European Craton, part II: Ukraine. Precambrian Research, 40, 106-282.

Peters, K. E., Walters, C. C. \& Moldowan, J. M. 2007. The Biomarker Guide. Vol. 2: Biomarkers and Isotopes in Petroleum Systems and Earth History, 2nd Edition. Cambridge University Press, New York, 704 pp.

Poprawa, P., Radkovets, N. \& Rauball, J. 2018. EdiacaranPaleozoic subsidence history of the Volyn-PodillyaMoldavia basin (W and S Ukraine, Moldavia, NE Romania). Geological Quarterly, 62, 459-486.

Radkovets, N. 2016. Lower Devonian lithofacies and palaeoenvironments in the southwestern margin of the East 
European Platform (Ukraine, Moldova and Romania). Estonian Journal of Earth Sciences, 65, 200-2013.

Radkovets, N., Kotarba, M. \& Wójcik, K. 2017a. Source rock geochemistry, petrography of reservoir horizons and origin of natural gas in the Devonian of the Lublin and Lviv basins (SE Poland and western Ukraine). Geological Quarterly, 61, 569-589.

Radkovets, N., Rauball, J. \& Iaremchuk, I. 2017b. Silurian black shales of Western Ukraine: petrography and mineralogy. Estonian Journal of Earth Sciences, 66, 161-173.

Radkovets, N., Kosakowski, P., Rauball, J. \& Zakrzewski, A. 2018. Burial and thermal history modelling of the Ediacaran succession in Western and SW Ukraine and Moldova. Journal of Petroleum Geology, 41, 85-106.

Radzivil, A. Y., Shulha, V. F., Ivanova, A. V., Machulina, S. O., Verhelska, N. V., Aleksandrova, A. V. \& Zaytseva, L. B. 2012. Etapy utvorennya vuhletsevykh formatsiy v heolohichnykh strukturakh Ukrayiny [Stages of Formation of Carbon Formations in Geological Structures of Ukraine]. LAT \& K, Kyiv, 215 pp. [in Ukrainian].

Sokolov, B. S. 1997. Ocherki stanovleniya venda [Essays on the Formation of the Vendian]. Nauchnoe izdatel'stvo KMK, Moskva, 142 pp. [in Russian].

Shul'ga, V. F., Zdanovskij, A., Zajtseva, L. B., Ivanova, A. V., Ivanina, A. B., Korol', N. D., Kotasova, A., Kotas, A., Kostik, I. E., Lelik, B. I., Miger, T., Manichev, V. I., Matrofajlo, M. N., Ptak, B., Savchuk, V. S., Sedaeva, G. M. \& Stepanenko, Y. G. 2007. Korrelyatsiya karbonovykh uglenosnykh formatsij L'vovsko-Volynskogo i Lyublinskogo bassejnov [Correlation of the Carboniferous Coal-Bearing Formation of the Lviv-Volyn and Lublin Basins]. National Academy of Sciences of Ukraine, Institute of Geological Sciences and Polish State Geological Institute, Upper
Silesian Branch, Kiev, 427 pp. [in Russian, with English summary].

Trushkevych, R. T. \& Shvay, L. P. 1998. Formuvannya pokladiv nafty $i$ hazu u zakhidnomu rehioni [Formation of oil and gas deposits in the western region]. Naftova $i$ hazova promyslovist, 4, 7-9 [in Ukrainian].

Vashchenko, V. O., Turchynova, S. M., Turchynov, I. I. \& Poliha, G. G. 2007. Derzhavna geologichna karta Ukrainy mashtabu 1:200 000. Karpatska seria. Arkush M-35-XXV (Ivano-Frankivsk) [State Geological Map of Ukraine at a Scale of 1:200 000. Carpathian Series. Sheet M-35-XXV (Ivano-Frankivsk)]. UkrDGRI, Kyiv [in Ukrainian].

Vecoli, M. 2013. The palaeobiology and geochemistry of Precambrian hydrocarbon source rocks. Marine and Petroleum Geology, 40, 1-47.

Velikanov, V. Y. 1985. Opornyj razrez venda Podolii [Basic Vendian section of Podolia]. In Vendskaya Sistema [Vendian System], pp. 35-66. Nauka, Moscow [in Russian].

Velikanov, V. Y. 2011. Ukrayinskyy hipostratotyp Vendskoyi systemy [Ukrainian hypostratotype of the Vendian system]. Geologichnyi zhurnal, 1, 42-49 [in Ukrainian, with English abstract].

Velikanov, V. Y., Aseeva, E. A. \& Fedonkin, M. A. 1983. Vend Ukrainy [Vendian of Ukraine]. Naukova Dumka, Kiev, 164 pp. [in Russian].

Zelizna, S. T., Plaksa, Y. P. \& Filts, D. I. 1971. Bituminologichne doslidzhennya mynkovetskykh vidkladiv Prydnistrovia [Bituminological study of the Mynkivtsi deposits of the Dnister area]. Geologiya i geokhimiya goryuchykh kopalyn, 25, 79-86 [in Ukrainian].

Zevin, L. S. \& Zavyalova, L. L. 1974. Kolichestvennyj rentgenograficheskij fazovyj analiz [Quantitative X-ray Phase Analysis]. Nedra, Moscow, 183 pp. [in Russian].

\title{
Ediacara orgaanikarikkad Kaluse kihid Lääne-Ukrainas ja Loode-Moldovas: mineraloogia, orgaanikasisaldus ning nafta- ja gaasipotentsiaal
}

\author{
Natalia Radkovets, Myroslav Pavlyuk, Yaroslava Yaremchuk ja Yuriy Koltun
}

Ediacara settekivimid esinevad Ida-Euroopa platvormi edelanõlval Mustast merest kuni Lublini-Podlasie basseinini. LääneUkrainas ja Loode-Moldovas sisaldab Ediacara ladestu kuni 90 m paksuseid orgaanikarikkaid Kaluse kihte. Samavanuselised orgaanikarikkad kivimid on mitmel pool maailmas nafta ja gaasi allikad. Käesolev töö tutvustab Kaluse kihtide geokeemiliste ja mineraloogiliste uuringute tulemusi ning süsivesinike lähtekivimite potentsiaali. Kaluse kihtides domineerib savikas aleuriit, milles esinevad kvarts (38-66\%) ja vilgud (8-19\%), samuti päevakivi (4-11\%) ja kloriit (4-12\%). Savifraktsioonis valdavad illiit, kloriit, kaoliniit ja illiit-smektiit. Segakihilisi savimineraale leidub kuni $150 \mathrm{~m}$ sügavuseni. Kaoliniit esineb laiemas sügavusvahemikus, kuid üle $3800 \mathrm{~m}$ ainult kloriit ja illiit. Selline mineraalne koostis ja kvartsi terasuurus viitavad kivimite rabedusele ning võimalusele kasutada hüdraulilist purustamist (frakkimist). Kaluse kihtide orgaanikasisaldus (TOC) varieerub vahemikus $0,1-0,89 \%$, ületades osal uuringualast $0,5 \%$. Seega võib neid kihte pidada potentsiaalseks süsivesinike lähtekivimiks. Kaluse kihtide orgaanika küpsusaste sõltub otseselt mattumissügavusest: kivimid on ebaküpsed kuni $100 \mathrm{~m}$ sügavuseni; nafta ja gaasi teke toimub u 100-2200 m ja 2200-3800 m vahemikes. Veelgi sügavamal on kivimid üleküpsenud. Uuringuala põhiosas on orgaanikarikkad Kaluse kihid olulise paksusega ning lasuvad nafta ja gaasi tekkeks sobival sügavusel. 